\title{
Of BRICs and mortar: the growing relations between Africa and the Global South
}

\author{
Maxi Schoeman ${ }^{1}$
}

\begin{abstract}
The ambitions of the global South for a larger share of global wealth and political power are at least partly being played out on the African continent. A snapshot of the scope and nature of the involvement of the BRICs and other emerging markets in Africa is provided, focusing on the economic (trade, investment and development assistance) and political spheres of these growing relations. The article concludes, first, that increasing Africa-South relations indicate a relative decline in Africa-North ties, that the shift in Africa's trade relations from North to South results in trade creation rather than trade diversion and that South partners provide much needed infrastructure development assistance to the continent. Politically these relations are formalised in a host of frameworks and associations and operate in fundamentally different ways from those between Africa and its erstwhile colonial masters. It is doubtful, though, to what extent Africa's capacity to influence the global agenda is strengthened, especially given that not a single African country is (yet) a member of the 'South Big Four', the BRIC.
\end{abstract}

\section{Introduction}

Few topics over the past several years have elicited as much debate, interest, speculation and sheer volume of commentary as that of the 'rise of new global actors/emerging powers', especially with reference to growing South-South relations and the increasing presence of China (and other South powers) in Africa. The rise of the emerging powers is often perceived and portrayed as 'new' - with 'new actors in Africa' in the spotlight, in contrast to 'old' actors associated with Africa's colonial and postcolonial history and development, viz. Europe and the United States. The impression is created that Africa-South relations are much more recent than Africa-developed countries relations and that the former are, for various reasons, creating cause for concern. The post-Cold War era was hailed to be inaugurating a new global order of peace, stability and the triumph of liberal democracy with large parts of the world remade in the image of the West. Yet, the first decade of the twenty first century has perhaps alerted us to the real contours of the new world order: one in which aspects of Western economic liberalism have globalised, but with new leading actors hailing from the global South, clamouring for a place at the table, with a new confidence and bringing their sheer economic and population weight as credentials, ${ }^{2}$ together with a strong sense of an entitlement to (co-)determine the global agenda ${ }^{3}$ and their own place and status in the global arena. For many of these countries

\footnotetext{
${ }^{1}$ Maxi Schoeman is Professor and Head of the Department of Political Sciences, University of Pretoria, South Africa.

${ }^{2}$ In an article titled 'New world order', 17 June 2010, Shawn Hattingh comments: 'The global power balance is simply widening to include the new elite of China and India in partnerhsiip with their American and European counterparts', Pambazuka News, www.pambazuka.org/en/category/africa; accessed 25 September 2010.

${ }^{3}$ At the UN General Assembly meeting in New York in September 2010, Africa demanded two permanent seats with veto rights and five non-permanent seats on the UN Security Council. India and Brazil, as members of the G4
} 
democratising international relations has become a main feature of their participation in the global system, based on an overriding concern for their own economic growth and development.

These ambitions of the global South are at least in part being played out on the African continent and this article deals with the nature of the relations between Africa and other South powers, focusing on the BRIC countries (Brazil, Russia, India and China), with the bulk of attention, though, to China, due to the sheer volume and scope of its interactions with Africa. The discussion is of necessity wide-ranging and descriptive, rather than analytical. In the first section attention is paid to the main reasons for the dramatic growth in Africa-South relations, followed in section two by an overview of the nature of these ties. It should be pointed out, though, that categories such as 'global South', 'Africa', 'BRICs' and 'developed countries' are of course not neat and uniform: there are huge differences between China's relations with Africa, and those of India, and there are 53 African countries with marked differences among and between them.

\section{Why Africa?}

In its overview of the potential of African economies for growth (and therefore as an investment opportunity), the McKinsey Institute highlights a number of positives on the continent under the heading 'Africa Today'4: the continent has a combined GDP of $\$ 1,6$ trillion, expected to reach $\$ 2,6$ trillion by 2020; consumer spending in 2008 stood at $\$ 860 \mathrm{bn}$, and $60 \%$ of the world's uncultivated arable land is in Africa. Furthermore, the Report points out that only $24 \%$ of GDP growth on the continent between 2000 and 2008 was as a direct result of natural resources exports and that GDP grew at similar rates in countries with and without natural resources exports. ${ }^{5}$ The message seems to be, quite literally, that 'Africa is on the move' and therefore attractive to foreign investors or those looking to expand consumer markets. Yet these figures need to be interpreted in a more nuanced way, and this article argues that external interest in Africa, from the BRICs and other emerging economies, goes further and deeper than these 'headline figures'.

Although the involvement of BRIC countries, and particularly that of China, in Africa is often portrayed as simply a self-interested search for natural resources to fuel the insatiable growth demands of the rising giants, such a perspective is an over-simplification of the scope, depth and nature of the ties that bind Africa and the BRICS (and other emerging powers in the 'second tier'). ${ }^{6}$ No doubt Africa's overabundance of a range of primary resources is a prime driver of this interest (as it is for relations with the developed world), yet a range of other aspects of these relations is as important in the development of Africa-South cooperation and interaction, at least in the way in which interaction between the BRICS and other emerging markets with Africa is being framed.

(which also included Japan and Germany) are also lobbying for Security Council reform and permanent representation on the Council.

${ }^{4}$ McKinsey Institute, Lions on the Move, $\mathrm{p}$ vi.

${ }_{6}^{5}$ McKinsey Institute, Lions on the Move, $\mathrm{p} 2$.

${ }^{6}$ For a comprehensive overview of the history of China and India's relations with Africa, see section two of The Rise of China and India in Africa. 
In an article titled 'China's exceptionalism in Africa: from Rhetorical to Substantive Difference?', Alden and Large discuss the form of Chinese power in Africa as 'exceptionalism' - a relationship 'informed by a discourse of difference and similitude ${ }^{7}$ in which the moral basis of China's involvement in Africa is presented as 'categorically different' from that of all previous external actors on the continent as it shares with African states the 'seminal experience' of being a developing country. Inherent in the understanding of 'developing country' is the implication of a shared history of external Western subjugation, exploitation and interference contrary to international norms of respect for sovereignty, non-intervention and the equality of all states. Africa's colonial history and post-colonial experience at the hands of Western powers and its continuing underdevelopment and economic marginalisation resonate well with the Chinese approach and make for strong relations between China and African governments.

The sense of 'difference and similitude' discussed by Alden and Large also explains the moral basis and the discourse of relations (and aspirations) of other emerging powers with Africa, even though the scope and depth of these relations, especially with reference to economic and commercial ties, are less comprehensive than those between China and Africa. The idea of shared historical experience characterised by Western exploitation ${ }^{8}$ and of these new ties being fundamentally different and therefore almost automatically 'better', underlie and inform Africa's growing relations with the South. In the cases of India ${ }^{9}$ and Brazil, ${ }^{10}$ the shared historical experience has even more resonance, with almost half of Brazil's population claiming descent from African slaves ${ }^{11}$ and strong cultural, religious and linguistic ties between Brazil and Africa's lusophone countries. At least $10 \%$ of India's diaspora lives in Africa with a sizeable community in South Africa tracing its origin back 150 years to an era during which Indian indentured labour was used to build the large sugar farms in the country. India, as a previous British colony, furthermore shares a history of anti-colonial struggle with Africa, and was the first developing country to address the issue of racial discrimination in South Africa in the early years of the twentieth century. Relations with Russia are also not new, and the former USSR played a major role on the continent during the Cold War era, often in competition with China. In the case of India and China, trade relations with Africa span at least five centuries, but without these ever being formalised in a politically hierarchical or subordinate way. No doubt then, the 'moral basis' of these relationships is being framed in a manner which sets the growing relations between the countries of the South with Africa in a purposeful way as being inherently and categorically different from those of the North with Africa.

Stepping back from this framing of the moral basis for Africa-South relations and looking at the patterns of interaction, especially at the level of economic ties, from the outside in, as it were, one is struck by the fact that despite the discourse of mutual benefit and respect and political equality, the relations much resemble a kind of 'second scramble for Africa'. The core assumption is still that of a consumption-

\footnotetext{
${ }^{7}$ Alden and Large, 'China's exceptionalism in Africa', p 1.

${ }^{8}$ See Medeiros and Fravel, 'China's New Diplomacy'.

${ }^{9}$ See e.g. Thako and Qobo, 'India-South Africa Relations'.

${ }^{10}$ See e.g. Doelling, 'Brazil's Contemporary Foreign Policy Towards Africa'.

${ }^{11}$ Harsch, 'Brazil Repaying its "Debt" to Africa', p 3.
} 
driven capitalist growth model dependent on industrialisation and the need for natural resources to fuel the growth. As was the case during the colonial era and the 'first scramble for Africa', newly industrialising economies now also depend on African raw materials to drive their economic ambitions and the 'dynamics of the new scramble [still] clearly lie outside Africa'. ${ }^{12}$ And although analyses of Africa's relations with its external environment are increasingly focusing on Africa-South interaction, it should be kept in mind that the difference between Africa-South relations and Africa-North relations lies largely in the discourse framing these relations and not so much in the type, or scope, of relations. Both developed and developing economies need (and vie for) Africa's resources. The difference lies in the fact that the emerging powers interact with Africa free of the North's historical baggage and in a global environment which is still largely governed by the rules of the North, whilst these power relations are being challenged by the emerging powers. Another notable difference lies in the way in which these claims of equality and solidarity find their formalised expression (see below). Claims of equality, solidarity and mutual support, however theoretical, ring much truer for Africa-South relations than for Africa-North relations, especially as Africa can point to and argue that exploitation - whether economic or military - by developed countries continue apace. ${ }^{13}$

\section{An overview of Africa-BRIC relations}

UNCTAD's Economic Development in Africa Report 2010, subtitled 'South-South Cooperation and the New Forms of Development Cooperation' provides an excellent overview of current relations between Africa and the South, encompassing a broader approach than the more conventional emphasis on Africa-BRIC or Africa-China. The Report points out that relations were originally focused almost exclusively on political cooperation (the post-independence era until circa 2000), but has over the past decade become increasingly driven by economic considerations, often formalised in partnership frameworks that allow for dialogue forums and action plans ${ }^{14}$ (the Forum of China-Africa Cooperation FOCAC - serves as a good example, as does the India-Africa Forum convened for the first time in 2008; and in 2005 a New Asian-African Strategic Partnership - NAASP - was established).

Table 1 here

The broad features of Africa's relations with the South are summarised in Table 1. At the root of these burgeoning relations is the aim of pursuing common development goals. Overall, these new partnerships emphasise principles such as mutual respect, reciprocal benefits, respect for sovereignty and non-interference in the internal affairs of partners; these principles to some extent reflect what many South countries perceive to be exactly what is missing in their relations with developed countries and such sentiments are often expressed during meetings and summits between African countries and

\footnotetext{
${ }^{12}$ Southall, 'Scrambling for Africa?', p 27.

${ }^{13}$ See for instance Lee, 'Trade Relations between the European Union and Sub-Saharan Africa'; Standing, 'The European Union and the International Scramble for African Fish' and Keenan, 'The banana theory of terrorism'.

${ }^{14}$ UNCTAD, Economic Development in Africa, p10.
} 
their South partners. Ghana's President Mills summed up the feelings of many African leaders in a speech during a September 2010 visit to Beijing: 'China is bringing investment, expertise and knowledge for the benefit of the African people in a bid to help the continent to regain its rightful place, to achieve rapid progress. ${ }^{15}$

The relations between Africa and external South actors are driven by governments, but private sector participation in the field of economic interaction is growing, as are civil society relations and networks, and academic contacts and interests between these countries, with South Africa in Sub-Sahara Africa taking the lead in many of these areas and establishing centres and institutes, and other formal relations in a number of universities in order to study Africa-South relations. ${ }^{16}$

\section{The scope of economic interaction}

The most salient feature of Africa-South economic relations is emerging markets' needs for Africa's abundant natural resources and it is this aspect that often causes apprehension, with a fear that the structure of trade relations will reinforce Africa's role as a provider of primary products, leaving it on the margins of the global economy - vital to the growth of that economy, but not benefiting from the advantages that go with the growing sophistication of industrialising economies, such as diversification, added value, growing skilled labour and, overall, more economic development. This fear is borne out by trade figures and the composition of trade between Africa and the BRIC countries.

Table 2 here

Table 2 indicates that the BRICs' exports to Africa are growing exponentially. In turn, Africa's exports to non-African developing countries consist mainly (90\%) of primary products (see Figure 1). In this regard, two aspects are of particular importance. First, a large percentage (67\%) of these exports consist of fuels (oil, gas and coal), meaning that a very small number of African countries, such as Angola, Nigeria and Sudan, are the main beneficiaries of these export earnings. This is one area in which generalisations can therefore be misleading - many African countries are not resource-rich and therefore do not reflect growing exports to non-African developing countries. Linked to this aspect, is the fact that exports of non-primary products is shrinking relative to primary product exports.

Figure 1 here

\footnotetext{
${ }^{15}$ Mills, quoted in China Daily, 23 September 2010.

${ }^{16}$ Over the past decade, the University of the Witwatersrand (Wits) has established a Centre for Indian Studies in Africa; Stellenbosch University and the Gordon Institute of Business Studies (GIBS) at the University of Pretoria focus on China-Africa relations and several research institutes have programmes focusing on relations between emerging markets and Africa, e.g. Fahama and the South African Institute of International Affairs. What is interesting is that up to very recently when the University of Pretoria established a Research Unit on Euro-African Studies, no university in South Africa ever developed or established dedicated research capacity focusing on the country/continent's relations with the developed world.
} 
Second, the structure of Africa's exports to the South is very similar to that of the continent's exports to developed countries, with primary products accounting for $92 \%$ of exports to the US and $75 \%$ to the EU (see Figure 1). It is these figures that cause unease, pointing to a repeat of the history of Africa-US/EU relations and a pattern reminiscent of colonial and post-colonial trade relations with the developed world. Closely linked to this point, and illustrated in Figure 2, is the fact that the composition of Africa's imports from the developing South is concentrated in technology manufactures, again confirming fears that the rapidly growing trade relations with developing economies might be indicative of economic growth on the continent, but not of economic diversification.

Figure 2 here

What the growing trade between Africa and non-African developing countries tells us, is that the share of the developed world in trade with Africa is shrinking relative to the continent's trade with the South. According to the McKinsey Institute, ${ }^{17}$ what we are seeing is a geographic shift of African trade relations from West to East, with Asia's share of these relations doubling between 1990 and 2008, and Europe's share contracting from $51 \%$ to $28 \%$. Second, this geographical shift, although still heavily dominated by natural resources exports and a lack of structural change in African economies, does indicate a diversification of trade partners and therefore Africa's traditional trade dependence on developed world countries is lessening, and the continent is increasingly tied into strong trade relations with the world's fastest growing economies.

A second feature of growing Africa-South economic relations is that of foreign direct investment (FDI) in Africa, although in this area the increase in South involvement in Africa is much smaller than in the case of trade. According to UNCTAD ${ }^{18}$ FDI inflows from emerging economies into Africa increased only marginally from $17,7 \%$ of world totals in $1990-1999$ to $20,8 \%$ in the period $2000-2008$. These FDI flows are driven by the search for natural resources and the frequent involvement of governments and statesowned enterprises is a particular feature of these investments with the most obvious examples being those of Petrobas (Brazil), Petronas (Malaysia), the China National Offshore Oil Corporation and India's Oil and Natural Gas Corporation. FDI for the creation of markets is a close second to natural resource motives with cultural and linguistic factors often underlying these investments, e.g. Brazilian corporations investing in lusophone African countries and Arab countries concentrating on North African countries, ${ }^{19}$ much as has been the case with European investment in Africa often following historical colonial patterns (francophone-France and Anglophone-British). Interestingly, though, the bulk of South

\footnotetext{
${ }^{17}$ McKinsey, Lions on the Move, p.15.

18 UNCTAD, Economic Development in Africa, p 81.

19 UNCTAD, Economic Development in Africa, p 82.
} 
FDI in Africa (specifically in stocks) flows from Asia, with Singapore as the biggest investor, followed by China, Hong Kong, Malaysia and India; Brazil is in $11^{\text {th }}$ place, lagging behind Pakistan and Chile. ${ }^{20}$

Three aspects of South-Africa FDI are of particular importance for an understanding of the extent to which growing interaction between Africa and the big emerging economies indicates deep changes in the global political economy. The first relates to the fact that a significant amount of the investment of emerging markets in Africa is aimed at infrastructure development on the continent. Because this is also the focus of development assistance, it will be discussed in more detail below.

A second aspect pointing to deep changes in the global political economy has to do with the extent to which a significant portion of South FDI in Africa focuses on the continent's agricultural sector. As mentioned earlier, Africa has $60 \%$ of the world's uncultivated, arable land and this is perhaps the one natural resource not often taken into account in overviews of external actors' interests in Africa. Food security is generally believed to be of growing importance internationally, especially so in light of global climate change, rising food prices and heavy population pressure in a number of emerging markets, most obviously so in arid Arab countries and in China and India. There is also strong evidence of interest in arable land for purposes of bio-fuel production. African countries targeted for investment in land with a view to export driven agriculture and bio-fuel production are Sudan, Ethiopia, Madagascar, Mozambique, Tanzania, Ghana, Kenya and Mali, and within the South investment in these economies is led by China, Korea, Saudi Arabia and Qatar. ${ }^{21}$ As is the case with the bulk of growing interaction between Africa and emerging economies, the basic pattern of interaction is very similar to the continent's interaction with developed economies: large US and UK companies are also investing in land on the continent and have been doing so for decades, though the difference between the two sources of investment seems to lie in the fact that South countries' investments in land in Africa are government backed and very much focused on food security, rather than 'merely' profit seeking. ${ }^{22}$

Looking back at the history of the economic growth and development of the 'Asian Tigers', a third aspect of FDI flows into Africa concerns China's plans, first announced in 2009, of investing in industrial development zones across the continent as part of its 'going global' strategy. In effect, this is an indicator that China might be moving its low cost manufacturing base offshore. The development of industrial zones may bring Africa, as the 'last economic frontier in the global production chain', ${ }^{23}$ firmly into the global division of labour as a manufacturer, thereby ensuring the genesis of economic diversification. Yet, such a shift, important though it may be in a traditional industrial development model, also poses serious questions regarding, e.g. environmental sustainability, whether African

\footnotetext{
${ }^{20}$ UNCTAD, Economic Development in Africa, p 86.

${ }^{21}$ See Cotula et al., Land Grab or Development Opportunity for a fairly detailed study of these investments; also Freemantle and Stevens, BRIC and Africa.

${ }^{22}$ Cotula et al., Land Grab or Development Opportunity, p 17.

${ }^{23} \mathrm{Naidu}$, 'Africa becoming low cost manufacturing hub', p 2.
} 
governments would elect to ensure the protection of workers' rights and whether the planned low cost manufacturing hubs would benefit from preferential trade agreements with other regions. ${ }^{24}$

The bulk of Indian investment in Africa, on the other hand, is in the continent's telecom industry with large Indian firms such as Bharti's $\$ 10,7$ billion acquisition of the African assets of Zain early in 2010, and Essar Telecom in late 2010 in the process of acquiring controlling stakes in Marid, a company operating in Uganda and Congo-Brazaville. ${ }^{25}$ This kind of investment is of course completely different from that of China. As to Russia, commentators seem to view its increasing interest in Africa (though falling far behind India and China), as 'a move to create a bloc of countries rich in energy resources. ${ }^{26}$

Another dimension of BRIC and South economic interest and involvement in Africa concerns that of development aid and assistance, an aspect often attracting criticism and concern from developed countries. Woods ${ }^{27}$ refers to western commentators becoming 'more anxious and vociferous about the emerging donors.... ${ }^{28}$ Official flows from the BRICs and other South countries into Africa (including official development assistance) are closely tied to the trade and investment activities of these countries, especially of India and China, ${ }^{29}$ with the flows not channelled through official development agencies as is the case with traditional donors, but usually through export-import banks, making it difficult to disaggregate development assistance from finance and other commercial interest flows. Yet this 'problem' also reflects a different approach to 'aid' on the part of South countries, especially those not part of the OECD Development Assistance Committee (DAC), such as China and India, in that such development assistance is politically and ideologically motivated as 'expressions of solidarity and cooperation borne out of shared experiences and sympathies'.$^{30}$ Somewhat more cynically one can also point to the fact that such official assistance is often concentrated in those countries on which emerging powers are most dependent for natural resources and aimed at the development of infrastructure that would facilitate natural resource exports. Yet, in the case of both China and India, there is evidence that development assistance also flows to African countries that are not resource rich, though such assistance is often aimed at smaller projects. ${ }^{31}$

Apart from the 'untied aid' provided by many non-DAC countries to Africa, there is a crucial difference between DAC and non-DAC development aid which is perceived by many African governments to reflect the core distinction between their relations with the developed world and with the South: Southern partners tend to concentrate their support in the infrastructure and production sectors of African recipient countries in stark contrast to DAC assistance which tends to favour the social sectors in African countries. ODA focused (almost) exclusively on the social sector of recipient countries cannot but be

\footnotetext{
${ }^{24}$ Naidu, 'Africa Becoming low cost manufacturing hub', p 2; Perez, 'China, World Bank plan industrial development zones'.

25 'Indian Telecoms moving West', http://biz.zeenews.com/interviews/story.aspx?newsid=157.

${ }^{26}$ Filatova, I. 'Russia's plans for Africa', p1. See also Qobo, M. 'Zuma's state visit' pp1-4.

${ }^{27}$ Woods, N. 'Whose aid?', p 1206

${ }^{28}$ See e.g. Nain, 'Rogue Aid', p 96.

${ }^{29}$ Woods, 'Whose aid?', p 1210

${ }^{30}$ UNCTAD, Economic Development in Africa, p 49.

${ }^{31}$ Davies et al., 'How China delivers development assistance', p 2-4.
} 
perceived as interfering, prescriptive and patronising, and as out of touch with 'realities on the ground', underlying the expression 'Africa can't eat democracy'. ${ }^{32}$ Here lies the rub for many DAC donors: building democracy and the core values of a democratic state - a strong civil society, rule of law, adherence to human rights etc., might be desirable, but for many African countries the overriding concern is economic growth, viewed as the solution to under-development, poverty, disease and other socio-economic ills. To them the kind of assistance provided by South partners, particularly China, promises deliverance. The West's earlier panacea, through the IMF and World Bank's structural adjustment programmes (SAPs), in many instances made matters worse for Africa. From an African perspective of course, criticism of South aid to the continent rings hollow. Africa can point to a string of broken promises on aid on the part of the West, ${ }^{33}$ whilst the aid that does reach these countries is disbursed through increasingly cumbersome and complicated sets of procedures, ${ }^{34}$ unsurprisingly resulting in a sense of resentment on the part of recipient countries.

It is generally assumed that the biggest threat to or stumbling block in Africa's development is lack of infrastructure. ${ }^{35}$ The continent has a huge infrastructure deficit, estimated to be US\$10bn per year, ${ }^{36}$ at least to some extent attributable to the very high cost of infrastructure development and low (and slow) return on investment which inhibits private sector investment in this sector. South countries and investors have stepped into the breach, assisting the continent to address this biggest of obstacles to its economic development. The sectors most affected by the lack of infrastructure are power and transport, both of which are crucial to economic development and to spill-over benefits to overall quality of life. Another sector that has been identified is that of telecommunication, yet this sector does attract FDI outside of development assistance with investors from developing countries, including South Africa, ${ }^{37}$ at the forefront.

China provides an interesting example of African infrastructure development. Although its support goes mainly to a small number of African oil-exporting countries (Angola, Sudan, Nigeria), it is increasing the geographical scope of such assistance and by 2008 at least 35 African countries were benefiting from Chinese assistance in the power and transport (particularly railways) sectors.

The Chinese construction industry has also grown into the largest globally, and has become the most successful contractors when it comes to tendering for projects funded by international multilateral aid agencies such as the World Bank and the African Development Bank, especially in the road and water sectors of African countries. ${ }^{38}$ In many African countries, therefore, China is becoming synonymous with infrastructure development - not only does it provide much-needed assistance, but its contractors are

\footnotetext{
${ }^{32}$ Fin24, 'WEF: "Africa can't eat democracy"' - a report on South Africa's President Zuma's speech at the World Economic Forum meeting in Davos in May 2010.

${ }^{33}$ Woods, 'Whose Aid?', p 1213.

${ }^{34}$ See e.g. De Renzio and Hanlon, 'Contested sovereignty in Mozambique'.

${ }^{35}$ For a fairly recent overview, see Foster et al's World Bank Report, Building Bridges.

${ }^{36}$ Foster et al., Building Bridges, p23.

${ }^{37}$ Szabo, 'As the BRICs go into Africa'.

${ }^{38}$ Foster et al, Building Bridges, $\mathrm{p}$ ix.
} 
carrying out much of the construction work. Add to this the way in which China (and India) projects its development assistance as mutual assistance, as coming from a country that understands the needs and requirements of other poor and developing countries and as assistance without any strings attached, and it becomes clear why Chinese aid in particular is perceived as without any (political) strings attached and without interference in the internal (again, political) affairs of the recipient country and therefore preferable to ODI as defined and provided by DAC donors.

One important aspect not dealt with in this overview of Africa-South relations, is the level of intra-South and/or intra-BRIC competition in various sectors of the global economy, especially in the sphere of access to natural resources. ${ }^{39}$ In the longer term, though, it would be interesting to see whether such competition would change the behaviour of these powers in Africa into a pattern more similar to that of the developed economies' approach to Africa, with the overt 'South solidarity' currently in evidence more muted or even disappearing. ${ }^{40}$

\section{Political interests}

Usually Africa-South relations are presented and analysed with an overwhelming emphasis on economic ties, underestimating the importance of politics as part of the key strategic interests that drive growing South cooperation. In this section brief attention will be paid to the nature and scope of these relations, focusing in particular on the formal frameworks for the conduct of these relations and the underlying values and objectives being pursued.

Establishing formal frameworks to govern economic and political relations between African countries and external actors is nothing new. The European Union's Lomé Agreements covering the AfricanCaribbean-Pacific (ACP) countries, and later succeeded by the Cotonou Agreement and currently being re-negotiated in the form of economic partnership agreements (EPAs) is but one example of a formal framework governing economic and political relations between Europe and a large part of the developing world, though the obvious characteristic of this arrangement, at least from an African perspective, is the inherent inequality of the relationship, borne out by critiques of the EPA negotiations. ${ }^{41}$ Broader political relations, focusing specifically on institution building and a broad range of security issues are captured in the 2007 Joint Africa-European Union Strategic Partnership established by the December 2007 Lisbon Declaration.

Similarly, a range of formal frameworks have been established between Africa and some of the emerging powers. The Forum on China-Africa Cooperation (FOCAC), established in 2000 is perhaps the best known formal framework within which Africa-South relations are played out, and it could be argued that the EU-Africa strategic partnership, the fairly recent India-Africa Forum, the Korea-Africa Forum,

\footnotetext{
${ }^{39}$ See e.g. Shaw et al., 'Global and/or Regional Development', p 1.

${ }^{40}$ See Nayyar, 'China, India, Brazil and South Africa', p 16.

${ }^{41}$ See e.g. Gibb, 'Can EU partnership agreements develop Africa?'
} 
the Brazil-Africa Forum and the renewed attention being paid to Afro-Arab relations ${ }^{42}$ all take their cue from FOCAC. A number of aspects regarding global South frameworks need to be examined closer.

The first has to do with membership. Whereas the EU-AU partnership and the EU's EPAs with various sub-regional combinations of African states are interregional, as is the Afro-Arab Summit framework being developed, India, Brazil and China's engagement with Africa is largely based on a 'many for the price of one' principle - FOCAC encompasses more than 40 African states. Some would argue that these powers (India, Brazil, Russia and China) are increasingly, like their Western counterparts, treating Africa as a 'single' country, scoring easy triumphs in a kind of photo opportunity way through their regular summits. This is a somewhat simplistic argument which ignores the strong tendency amongst African governments to preserve and pursue a pan-African, unitary image and policy, and the fact that the details of these formal frameworks for cooperation are still spelled out and implemented through bilateral negotiations and agreements between the external South actors and their African counterparts.

Second, although a type of multilateral approach to formal frameworks seems to be the preferred mode of institutionalising relations between external actors (whether from the South or the developed world) and Africa, the level of formalisation of cooperation between and amongst the emerging powers is also on the increase, giving further prominence to these associations and providing members with official means of negotiating and driving joint agendas. The acronym BRIC, coined by Goldman Sachs in 2001 took on a life of its own ${ }^{43}$ and is currently, though not formally institutionalised, characterised by regular interaction between these countries. It has become in many ways synonymous with the shift of economic power away from the developed world (especially in its erstwhile concentration in the G7) to the developing world. The extent of the BRICs as a purposeful political actor in pursuing mutual strategic interests is perhaps more dubious. If the power shift away from the developed world is more than an economic phenomenon and also a search for political power, the BRIC and IBSA are clearly pooling efforts and resources to push for changes. One example is their strong support for a restructuring of the Security Council to include additional veto-carrying members, specifically Brazil and India, and support for China's candidature to ECOSOC. ${ }^{44}$

There are, nonetheless, important differences between the BRIC countries. One such a difference is the fact that Brazil is not a nuclear arms power (though this is by choice), that relations between India and Russia and India and China have always been rather tense ${ }^{45}$ and that their domestic political systems differ dramatically, with India and Brazil as successful and consolidated democracies, China as an authoritarian country and both China and Russia having poor human rights track records. One could

\footnotetext{
${ }^{42}$ A first 'Afro-Arab Summit' was held in March 1977. A second summit, intent on formalising Afro-Arab relations with a view to much closer political and economic collaboration on an institutionalised basis, was held in Libya in October 2010.

${ }^{43}$ For a discussion of the differences between the BRICs across a wide range of indicators, see Armijo, 'The BRIC Countries' and MacFarlane, 'The " $R$ " in BRICs'.

44 'BRIC, IBSA boost India's drive of UN Seat', The Economic Times, 18 April 2010.

${ }^{45}$ See e.g. Kapila, 'Russia-China-India Triangle'.
} 
argue of course that similar differences in the past did not deter warm relations between developed countries and dictatorships across the developing world, especially during the Cold War period, and that should these countries agree to follow a 'Chinese model' of external relations (i.e. no intervention in the internal affairs of each other), there would be plenty room for a solid relationship. Currently, though, the BRIC association seems to be characterised more by the fact that they represent the four biggest and fastest growing developing world economies, than by a very specific rationale binding them together in pursuit of joint strategic benefits in the global arena. It would also seem that the BRICS are somewhat hesitant in flaunting their (potential political power) vis-à-vis the developing world and rightly so, as the idea of another club of rich countries prescribing and pontificating to Africa on 'how to govern' might easily upset the carefully constructed discourse of and on the nature of cooperation between the emerging powers and Africa.

In this regard it is interesting to note the apparent aloofness on the part of China in the EU's attempts to draw it into discussions on a kind of trilateral relationship with Africa in which the EU and China would be the dominant partners. ${ }^{46}$ At the same time, though, there also seems to be a sense of the need for South leadership in global issue areas and the recently formed BASIC grouping, constituting Brazil, South Africa, India and China, focused on issues of climate change, provides a good example of the extent to which these countries are assuming leadership of the South. Also of interest is the level of influence that they seem to exert globally, judged by their performance at the Copenhagen Summit of December 2010 which not only hailed the firm arrival of the South on the scene, but also indicated the relative decline in the importance and influence of the European Union as a global actor. Yet, at the same time, the big emerging powers may already be getting a taste of the contentiousness surrounding 'big' and the difficulties of delivering on promises - a problem up to now largely experienced by the developed countries: the Alliance of Small Island States (AOSIS) is already demanding of it to 'show more ambition in countering climate change' and the group (BASIC) has, according to some reports, been backtracking on some of their positions at Copenhagen. ${ }^{47}$

A last formal cooperative framework to be mentioned is IBSA - the association of India, Brazil and South Africa - established in 2003 with a view to promote closer ties between these countries as indisputable powerhouses in their respective regions. This association is of especial importance to South Africa, granting it a level of international status and prestige denied to it by the BRIC formation of which it does not form part, though it would clearly want to be the ' $S$ ' in the BRIC and is working hard at being admitted to what it views to be a rather exclusive club $^{48}$ and motivating its keenness at least partly on the 'need' for having Africa represented in the grouping. Apart from its focus on development issues,

\footnotetext{
${ }^{46}$ See e.g. Godement, 'A Global China Policy'.

47 'BASIC Group Determined to Lead on Climate Change', 27 April 2010.

${ }^{48}$ During the course of 2010 South Africa's President Jacob Zuma undertook high profile visits to all four BRIC countries in an effort to gain admission to the association, as well as to promote South Africa's economic ties with the BRICs and to lobby their support for South Africa's candidature for a second term as a non-permanent member of the Security Council. Zuma announced during his visit to China on 25 August 2010 that the country had formally applied for membership of the BRIC.
} 
IBSA is used by all three its members to push a concerted effort for the reform of the UN Security Council and other multilateral institutions. ${ }^{49}$

Although membership of these various South associations and frameworks provides some indication of the political and strategic agendas being followed by them, it would still seem that economic relations are dominant. Whereas within the BRIC and IBSA formations an argument could be made for the pursuit of various strategic objectives, it is less clear that those frameworks for Africa-South relations, such as FOCAC, amount to more than moral support and the provision of examples of domestic political regimes conducive to economic development. This is not to underestimate the importance of such support and examples. India and Brazil, as vibrant democracies, set important examples to the vast majority of African countries still very much battling to safeguard and build democracy. ${ }^{50}$ To countries in the Southern African region, India furthermore proves that the post-colonial state can be successfully governed (i.e. without a 'relapse' into pro-Western politics) by post-liberation political parties and its example might wean existing ruling parties who continue to rely on their 'liberation credentials' as justification for ruling in perpetuity from their conviction that their role in the anti-colonial struggle entitles them to cling on to political power. However, China's domestic political model might prove to be more attractive: the overwhelming strength and scope of China's involvement in Africa, dwarfing that of other emerging markets, might easily blind African countries to the nature of 'communist' rule in China. Rather, it could serve as a very good example and reason for not pursuing democracy too vigorously and here Zuma's 'Africa can't eat democracy'-comment again springs to mind.

In a nutshell, though, and probably as long as South Africa does not form part of the BRIC, the ability or capacity of these formal frameworks and associations to offer Africa opportunities to influence the global political agenda is rather negligent. This is not to say that the global South as a group will not be able to become important role players. Rather, Africa is still not a determining player. The reasons are complex and the topic of a separate study, but would seem, at the surface, to hinge on at least some of the following factors: First, individually African countries are small in all aspects used to measure economic and political success, be these population size, economic size, size of skilled labour force, military size or market size. To the extent that Africa matters, it is usually in the aggregate. Second, despite the shift away from trade and even donor dependence on the West, this is a relative shift and the extent of continuing dependence on the developed world should not be underestimated, meaning that the continent's political agenda is still largely dominated by the West. This is particularly true of the dependence of Africa's regional and sub-regional organisations on EU funding to actually operate, manage and build these institutions. One could therefore argue that it would be difficult for the continent to exert a prominent influence globally in conditions of deep dependence on external actors.

\section{Conclusion}

It is impossible to provide more than a snapshot of contemporary Africa-South relations and some pertinent aspects, most notably Western fears of China's interaction with 'rogue states' such as Sudan,

\footnotetext{
${ }^{49}$ Bissio, 'Emerging Powers Cooking Up'.

${ }^{50}$ Singh, 'India and West Africa', p1, 7, 11.
} 
have not been covered in this overview. Nevertheless, what is clear from an exploration of the level of economic interaction between Africa, the BRICs and other emerging markets is that although trade is expanding at an almost exponential rate, the 'decline' in trade with Africa's traditional developed world partners is relative. It is therefore not a case of trade diversion, but rather of trade expansion, due to two main reasons. First, economic growth in emerging markets demands natural resource inputs which are available from Africa. Second, the rate of economic growth in Africa, though from a low base, results in more income elasticity for African consumers. Simply put, ordinary Africans have, for the first time in almost three decades, some disposable income, however small and they spend their money on low-cost manufactures from emerging markets. The relative ease with which emerging economic powers, such as India and China, have managed to navigate the rocky seas of the global financial crisis of 2008 and its aftermath, and their continuing high levels of growth (in contrast to the sluggish performance of most developed economies), point to the possibility that the demand for Africa's natural resources will remain high.

Less certain is the extent to which countries such as Brazil and India, as examples of vibrant developing world democracies, would be able to influence political developments within African states. Despite their substantial and growing involvement in Africa, their economic contribution is dwarfed by that of China. The 'Chinese model of development', including its political system, might easily be adopted by African political elites as the ideal to strive for, especially in light of the fact that it so clearly benefits the top echelons of Chinese political society. ${ }^{51}$ In the words of Fantu Cheru, 'China is not very different from the West in how they operate in Africa. They are neither better nor worse.... ${ }^{52}$ Yet on the part of Africa there is a difference, or ought to be: in contrast to the colonial and post colonial/Cold War period, this time round the continent is engaging with the BRICs with their eyes wide open and should be very much alert to the fact that 'the BRICS need Africa as much as Africa needs the BRICS'. ${ }^{53}$ It is up to Africa to ensure that their relations with the new emerging markets do not plunge the continent into neocolonialism in which Africa is, once again, the only loser.

\footnotetext{
${ }^{51} 70$ per cent of China's wealth is owed by 0.04 per cent of its population, according to Zhong, 'China's "most wanted" millionaires'.

${ }^{52}$ Cheru, 'The rise of China and India in Africa'

${ }^{53}$ Freemantle and Stevens, BRIC and Africa, p 2.
} 


\section{Bibliography}

Alden, C. and Large, D. 'China's exceptionalism in Africa: from Rhetorical to Substantive Difference?' (25 August 2010). http://www.saiia.org.za/index.php?view=article\&catid=onent\&print.

Armijo, L. 'The BRICs countries (Brazil, Russia, India, and China) as Analytical Category: Mirage or Insight?' Asian Perspective 31 no. 4 (2007): 7-42.

Aslund, A. 'Take the $\mathrm{R}$ out of BRICs', Foreign Policy (2 December 2009). http://www.foreignpolicy.com/articles.

'BASIC Group Determined to Lead on Climate Change'. The Economic Times (27 April 2010). http://economictimes.indiatimes.com/news/politics/nation/

Bission, B. 'Emerging Powers Cooking Up New International Order'. IPS (27 September 2010): 1-3. http://ipsnews.net/print.asp?idnews=51075.

'BRIC, IBSA boost India's Drive for UN Seat'. The Economic Times (18 April 2010). http:www.economictimes.indiatimes.com/news/politics/nation/

Cheru, F. and Obi, C. eds. The Rise of China and India in Africa. London: Zed Books, 2010.

Cheru, F. 'The Rise of China and India in Africa'. Interview (undated) www.nai.uu.se.

Cohen, A. 'Russia's New Scramble for Africa', Wall Street Journal (2 July 2009). http://www.online.wsj.com/article.

Cotula, L., Vermeulen, S., Leonard, R., Keeley, J. Land Grab or Development Opportunity? Agricultural Investment and International Land Deals in Africa. London: IIED; Rome: FAO and IFAD. 2009.

Davies, M., with Edinger, H., Tay, N. and Naidu, S. 'How China Delivers Development Assistance to Africa' (February 2008): 1-4. Stellenbosch: Centre for Chinese Studies.

De Renzio, P. and Hanlon, J. 'Contested Sovereignty in Mozambique: The Dilemmas of Aid Dependence'. GBG Working Paper (2007). www.globaleconomicgovernance.org.

Doelling, R. 'Brazil's Contemporary Foreign Policy Towards Africa'. Journal of International Relations 10 (Spring 2008): 5-11.

Esanov, A. 'Russia Returns to Africa', Revenue Watch Institute (22 July 2009). http://www.revenueworld.org/news/news-article/Russia.

Filatova, I. 'Russia's plans for Africa', The Guardian. (26 June 2009). www.guardian.co.uk

Fin24. 'WEF: “Africa can't eat democracy"'. (7 May 2010) http://www.fin24.com.Econ.

Foster, V., Butterfield, W., Chen, C. and Pushak, N. China's Growing Role as Infrastructure Financier for Africa. Washington: World Bank. 2008.

Freemantle, S and Stevens, J. BRIC and Africa: Tectonic Shifts Tie BRIC and Africa's Economic Destinies. Johannesburg: Standard Bank. 2009.

Gibb, R. 'Can EU economic partnership agreements help develop Africa?' (2008). www.thebrenthurstfoundation.org.

Godement, F. 'A Global China Policy'. European Council on Foreign Relations Policy Brief (June 2010): 1-9. www.ecfr.eu

Harsch, E. 'Brazil Repaying its "Debt" to Africa', Africa Recovery 17, no. 4 (January 2004). http://www.un.org/ecosocdev/geninfo/afrec/vol17no4/17brazil.htm.

Kapila, S. 'Russia-China-India Triangle Strategically Inadvisable' (6 February 2002). http://www.saag.org/common/uploaded_files/paper408.html. 
Keenen, J. 'The banana theory of terrorism: alternative truths and the collapse of the "second" (Saharan) front in the war on terror'. Journal of Contemporary African Studies 25 no. 1 (2007): 31-58.

Lee, M. 'Trade Relations between the European Union and Sub-Saharan Africa under the Cotonou Agreement: Repartitioning and Economically Recolonising the Continent?' In A New Scramble for Africa? Imperialism, Investment and Development, edited by Roger Southall and Henning Melber: 83-110. Scottsville: University of KwaZulu Natal Press, 2009.

MacFarlane, S. 'The "R" in BRICs: is Russia an emerging power?' International Affairs 82, no. 1 (January 2006): 41-57.

McKinsey \& Company. Lions on the Move: The Progress and Potential of African Economies. (June 2010). http://www.mckinsey.com/mgi/publications/

Medeiros, E. and Fravel, M. 'China's New Diplomacy'. Foreign Affairs 82, no. 1 (January 2006): 22-35.

'Mills lauds China's Role'. China Daily (23 September 2010). http://www.chinadaily.com.cn/china201009/23/content 1138934.htm

Naidu, S. 'Africa Becoming Low Cost Manufacturing Hub for Chinese Investements'. (27 May 2010): 1-3. http://www.pambazuka.org/en/category/africa china/64759

Nain, M. 'Rogue Aid'. Foreign Policy (March-April 2007): 96-95 (sic).

Nayyar, D. 'China, India, Brazil and South Africa in the World Economy: Engines of Growth? UNU-WIDER Discussion Paper. (2008/05): 1-28.

Perez, E. 'China, World Bank plan Industrial Development Zones for Africa' (14 February 2009). http://farmlandgrab.org.9803

'President Jiang Zemin's Visit to Six African Countries'. Ministry of Foreign Affairs of the People's Republic of China (17 November 2000). http://www.fmprc.gov.cn/eng/ziliao/3602/3604/t18035.htm

Qobo, M. 'Zuma's state visit and the challenges of doing business in Russia' (12 August 2010) South African Institute of International Affairs.

Shaw, T., Cooper, A. and Antkiewicz, A. 'Global and/or Regional Development at the Start of the $21^{\text {st }}$ Century? China, India and (South) Africa.' Third World Quarterly 28 no. 7 (2007): 1-16.

Singh, S. 'India and West Africa: a Burgeoning Relationship' (April 2007): 1-16. London: Chatham House

Southall, R. 'Scrambling for Africa? Continuities and Discontinuities with Formal Imperialism'. In A New Scramble for Africa? Imperialism, Investment and Development, edited by Roger Southall and Henning Melber: 1-34. Scottsville: University of KwaZulu Natal Press, 2009.

Standing, A. 'The European Union and the International Scramble for African Fish'. In A New Scramble for Africa? Imperialism, Investment and Development, edited by Roger Southall and Henning Melber: 324-356. Scottsville: University of KwaZulu Natal Press, 2009.

Szabo, J. 'As the BRICS go into Africa, where does South Africa stand?' (15 July 2010).

http://www.pambazuka.org/en/category/africa china/65959.

Thako, V and Qcobo, M. 'India-South Africa Relations through the Shadow of Nehru-Mbeki Legacies' (12 August 2010). http://www.saiia.org/Index.php?view.

'Trans-Sahara gas pipeline "in trouble"'. United Press International (1 September 2010). http://www.upi.com/Science News/Resource-Wars.

UNCTAD. Economic Development in Africa Report 2010. New York: United Nations. 2010.

Zhong, D. 'China's "most wanted" millionaires'. Asia Times (19 September 2007). http://www.atimes.com. 
Woods, N. 'Whose aid? Whose Influence? China, Emerging Donors and the Silent Revolution in Development Assistance'. International Affairs 84, no. 6 (2008):1205-1221.

Table 1 - Broad features of Africa-South partnerships

\begin{tabular}{|l|l|}
\hline \multicolumn{1}{|c|}{ Feature } & \multicolumn{1}{c|}{ Description } \\
\hline Aim & $\begin{array}{l}\text { Promotion of Africa-South cooperation to achieve common } \\
\text { development goals }\end{array}$ \\
\hline Key principles & $\begin{array}{l}\text { Mutual respect, reciprocal benefits, respect for sovereignty and } \\
\text { non-interference in international affairs }\end{array}$ \\
\hline Mode of intervention & Forums, summits and bilateral agreements \\
\hline Key areas & Political, economic, social and cultural cooperation \\
\hline Accountability mechanism & Partnerships have inbuilt monitoring mechanisms \\
\hline Stakeholders & Mostly governments, but also private sector \\
\hline
\end{tabular}

Source: UNCTAD, Economic Development in Africa p 10

Table 2

\begin{tabular}{|l|c|c|}
\hline \multicolumn{1}{|c|}{ Country } & $\begin{array}{c}\text { \% Annual export rate growth } \\
\text { between 2000 and 2008 }\end{array}$ & 2008 total (US\$ Bn) \\
\hline Brazil & 19 & 16 \\
\hline China & 39 & 56 \\
\hline India & 32 & 23 \\
\hline Russia & 25 & 6,3 \\
\hline
\end{tabular}


Figure 1 - Composition of Africa's exports to main export partners (2008)

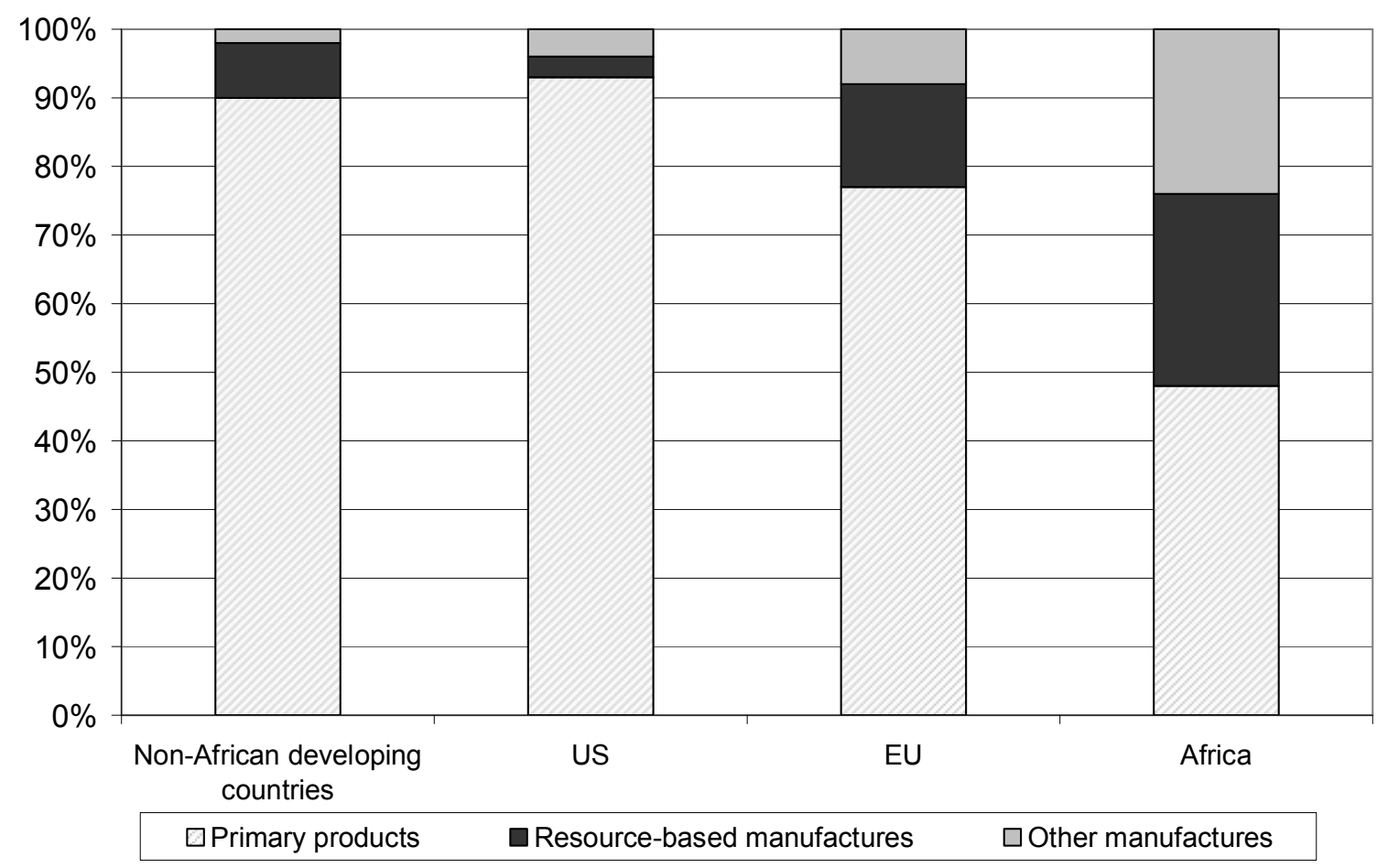

Source: UNCTAD, Economic Development in Africa, p 38. 
Figure 2 - Composition of Africa's imports from non-African developing countries (1995-2008)

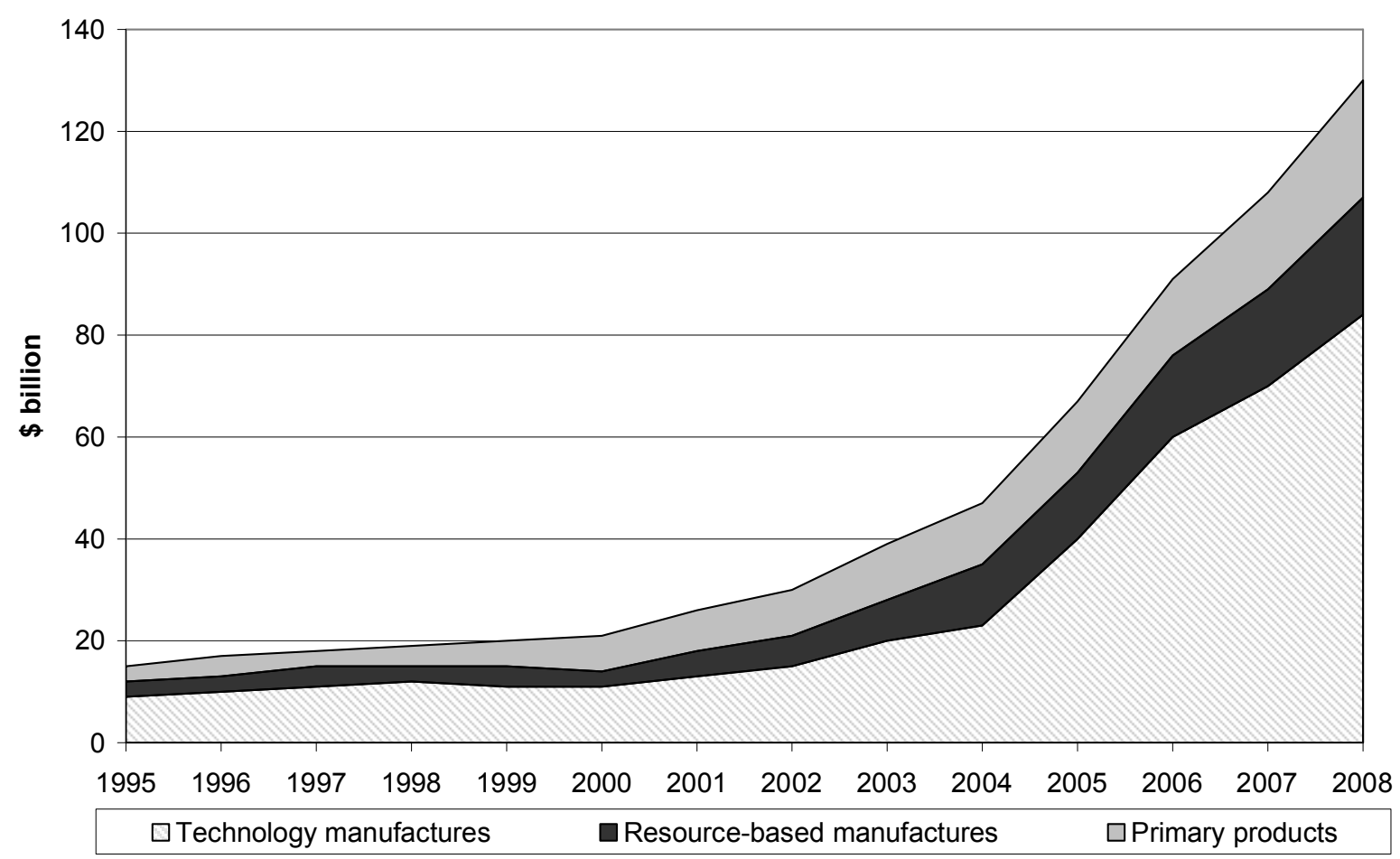

Source: UNCTAD, Economic Development in Africa, p 39. 